\title{
A Candida albicans cyclic nucleotide phosphodiesterase: cloning and expression in Saccharomyces cerevisiae and biochemical characterization of the recombinant enzyme
}

\author{
L. L. Hoyer, ${ }^{1}+$ L. B. Cieslinski, ${ }^{2}$ M. M. McLaughlin, ${ }^{1}$ T. J. Torphy, ${ }^{2}$ \\ A. R. Shatzman ${ }^{1}$ and G. P. Livi ${ }^{1}$
}

Author for correspondence: L. L. Hoyer. Tel: +1 510486 5468. Fax: +1 5104866816. e-mail: hoyer@genome.lbl.gov

Department of Gene Expression Sciences ${ }^{1}$ and Department of

Pharmacology 2 , SmithKline Beecham Pharmaceuticals, King of Prussia, Pennsylvania 19406, USA

\begin{abstract}
We have cloned a Candida albicans gene, which encodes a cyclic nucleotide phosphodiesterase (PDEase), by complementation in a Saccharomyces cerevisiae PDEase-deficient mutant. The deduced amino acid sequence is similar to that of the low-affinity PDEase of S. cerevisiae (PDE1) and the cyclic nucleotide PDEase (PD) of Dictyostelium discoideum. Biochemical analysis of recombinant protein produced in 5 . cerevisiae indicated that the enzyme behaves as a PDE1 homologue: it hydrolyses both CAMP $\left(K_{m}=0.49 \mathrm{mM}\right)$ and CGMP $\left(K_{\mathrm{m}}=0.25 \mathrm{mM}\right.$ ), does not require divalent cations for maximal activity and is only moderately inhibited by millimolar concentrations of standard PDEase inhibitors. Based on these data, we designate the $C$. albicans we have cloned, PDE1. Low-stringency genomic Southern blots showed crosshybridization between C. albicans PDE1 and DNA from Candida stellatoidea, but not with DNA from S. cerevisiae or several closely related Candida species.
\end{abstract}

Keywords: Candida albicans, cyclic nucleotide phosphodiesterase, morphogenesis

\section{INTRODUCTION}

The molecular basis of transition in growth between yeast (blastospore) and hyphal forms of the pathogenic fungus Candida albicans has been the subject of intensive research (reviewed by Odds, 1985). The ability to undergo morphogenesis is believed to confer greater pathogenicity on the organism (Sobel et al., 1984) or, minimally, provide a survival advantage in the host (Shepherd, 1991). Demonstration of cyclic 3',5'-adenosine monophosphate (cAMP) involvement in morphogenesis of Mucor species (Cantore et al., 1980; Larsen \& Sypherd, 1974; Paveto et al., 1975; Paznokas \& Sypherd, 1975) and Histoplasma capsulatum (Maresca et al., 1977) prompted several groups to investigate the role of cAMP in the yeast-to-hyphal transition in C. albicans. The results have been mixed, with reports of both increases (Niimi et al., 1980; Chattaway et

\footnotetext{
†Present address: Lawrence Berkeley Laboratory, Mail Stop 74-157, 1 Cyclotron Road, Berkeley, CA 94720, USA.

Abbreviations: IBMX, 3-isobutyl-1-methylxanthine; 2-ME, 2-mercaptoethanol; PDEase, phosphodiesterase.

The nucleotide sequence data reported in this paper have been submitted to GenBank and have been assigned the accession number L12045 (Gb_pl:YSAPDE1X).
}

al., 1981; Sabie \& Gadd, 1992) and decreases (Egidy et al., 1989 ) in cAMP levels just preceding or during germ tube formation; one study found no change in cAMP content during morphogenesis (Sullivan et al., 1983). As in most organisms, cAMP content is regulated by the combined action of adenylate cyclase and cAMP phosphodiesterase(s) [PDEase(s)], both enzyme activities having been detected in C. albicans (Egidy et al., 1990).

We believe that cloning genes encoding enzymes involved in regulating intracellular cAMP levels should provide tools for understanding how cAMP levels are modulated and how, if at all, they control the process of morphogenesis. Cells of Saccharomyces cerevisiae contain two cAMP PDEases encoded by the genes PDE1 (Nikawa $e t$ al., 1987; Suoranta \& Londesborough, 1984) and PDE2 (Londesborough \& Suoranta, 1983; Sass et al., 1986; Wilson \& Tatchell, 1988). PDE1 is a low-affinity (high$K_{\mathrm{m}}$ ) enzyme of $42 \mathrm{kDa}$, whereas PDE2 is a high-affinity $\left(\right.$ low $\left.-K_{\mathrm{m}}\right)$ enzyme of $61 \mathrm{kDa}$. PDEase-deficient mutants of $S$. cerevisiae are viable but sensitive to a variety of environmental stress conditions due to elevated intracellular cAMP concentrations (Colicelli et al., 1989; Nikawa et al., 1987; Sass et al., 1986; Wilson \& Tatchell, 1988). By complementation of the heat-shock sensitivity 
Table 1. Strain list

\begin{tabular}{|c|c|c|}
\hline & Genotype & Source/reference \\
\hline \multicolumn{3}{|l|}{ S. cerevisiae } \\
\hline F762 & $M A T \alpha \operatorname{trp} 1 \Delta 1$ ura3-52 & $\begin{array}{l}\text { G. R. Fink (Whitehead } \\
\text { Institute, Cambridge, } \\
\text { MA) }\end{array}$ \\
\hline RW134-2C & $\begin{array}{l}\text { MATa leu } 2 \text { bis } 3 \text { bis4 trp1 ura } 3 \\
\text { pde } 2:: U R A 3\end{array}$ & Wilson \& Tatchell (1988) \\
\hline GL62 & $\begin{array}{l}M A T \alpha \text { leu2 ura3-52 ade } 1 \text { bis3 } \\
\text { trp1 lys 2-208 pde1:: LEU2 } \\
\text { pde2:: UR A3 pep4:: HIS3 }\end{array}$ & McLaughlin et al. (1993) \\
\hline DC17 & $M A T \alpha$ bis1 & $\begin{array}{l}\text { J. B. Hicks (ICOS Corp., } \\
\text { Bothell, WA) }\end{array}$ \\
\hline \multicolumn{3}{|l|}{ C. albicans } \\
\hline B311 (ATCC 32354) & & ATCC (Rockville, MD) \\
\hline B792 & & $\begin{array}{l}\text { J. A. Gorman } \\
\text { (Bristol-Myers Squibb, } \\
\text { Princeton, NJ) }\end{array}$ \\
\hline \multicolumn{3}{|l|}{ C. stellatoidea } \\
\hline ATCC 11006 & & ATCC \\
\hline ATCC 36232 & & ATCC \\
\hline C. glabrata & & $\begin{array}{l}\text { C. Frey } \\
\text { (SmithKline Beecham, } \\
\text { King of Prussia, PA) }\end{array}$ \\
\hline C. guilliermondii & & C. Frey \\
\hline $\begin{array}{l}\text { C. keyfr } \\
\text { (ATCC 46764) }\end{array}$ & & ATCC \\
\hline C. krusei & & C. Frey \\
\hline C. lusitaniae & & C. Frey \\
\hline C. parapsilosis & & C. Frey \\
\hline C. tropicalis & & C. Frey \\
\hline $\begin{array}{l}\text { C. viswanatbii } \\
\text { (ATCC 22981) }\end{array}$ & & $\mathrm{ATCC}$ \\
\hline
\end{tabular}

of a PDE2-deficient $S$. cerevisiae strain, we isolated a $C$. albicans gene encoding an enzyme capable of cyclic nucleotide hydrolysis. This paper describes the molecular cloning and DNA sequence of this gene, its expression in $S$. cerevisiae and an initial characterization of the biochemical properties of the recombinant enzyme.

\section{METHODS}

Strains and media. Yeast strains used in this study are listed in Table 1. Cells of Escherichia coli strain DH5 aMCR (Gibco BRL) containing various plasmids were grown in Luria broth or on Luria agar plates (Sambrook et al., 1989) supplemented with $100 \mu \mathrm{g}$ ampicillin $\mathrm{ml}^{-1}$. For genomic DNA isolations, S. cerevisiae and Candida strains were grown in YEPD (Sherman et al., 1986). $S$. cerevisiae strains were grown on synthetic complete medium (Hicks \& Herskowitz, 1976) without leucine (SC-Leu) or tryptophan (SC - Trp) to select for plasmid maintenance.

DNA manipulations and transformations. Plasmid DNA was recovered from $E$. coli using the alkaline lysis method of Birnboim \& Doly (1979). Genomic DNA from C. albicans and $S$. cerevisiae was prepared using the method of Sherman et al. (1986). Competent E. coli cells were prepared according to
Stoker et al. (1984). Plasmids were introduced into $S$. cerevisiae by either the spheroplast (Hinnen et al., 1978) or lithium acetate method of transformation (Ito et al., 1983).

Isolation of genomic clones by complementation in $\boldsymbol{S}$. cerevisiae. PDEase-deficient mutants of $S$. cerevisiae exhibit growth-arrest phenotypes associated with elevated intracellular cAMP content, including heat-shock sensitivity (Nikawa et al., 1987; Sass et al., 1986; Wilson \& Tatchell, 1988). Cells of the heat-shock-sensitive strain RW134-2C (pde2: :URA3) (Table 1) were transformed with a YEp13-based $C$. albicans genomic library (Rosenbluh et al., 1985). Approximately 6000 clones with an average insert size of $5-10 \mathrm{~kb}$, representing $2-4 \mathrm{C}$. albicans genome equivalents were screened. Transformants were grown at $30^{\circ} \mathrm{C}$ from regeneration agar and re-plated on SC-Leu. Colonies were replicated to SC-Leu plus $5 \mathrm{mM}$ cAMP and incubated for $2 \mathrm{~d}$ at $30^{\circ} \mathrm{C}$; the addition of cAMP accentuates the heat-shock phenotype displayed by RW134-2C (Wilson \& Tatchell, 1988). Colonies were replicated to fresh plates of the same medium which had been preheated at $55^{\circ} \mathrm{C}$ for $1 \mathrm{~h}$, then shifted to $55^{\circ} \mathrm{C}$ for $2 \mathrm{~h}$, and transferred to $30^{\circ} \mathrm{C}$; growth was monitored for $7 \mathrm{~d}$.

A single colony was isolated following the heat-shock protocol and tested for co-segregation of the $\mathrm{Leu}^{+}$and heat-shock- 
resistance phenotype during growth on nonselective (YEPD) media. Mitotic instability was observed for both phenotypes. Plasmid DNA was recovered, reintroduced into cells of RW134$2 \mathrm{C}$, and found to confer heat-shock resistance; the plasmid was designated pLH41. Subfragments of the $9 \mathrm{~kb}$ pLH41 insert were subcloned into YEp351 (Hill et al., 1986) and retested for activity via heat shock. The insert from the smallest active subclone, a $4.5 \mathrm{~kb} \mathrm{Bam} \mathrm{HI}-H i n \mathrm{dIII}$ fragment, was shuttled into pUC19 for DNA sequencing.

DNA sequencing and sequence analysis. DNA sequencing was performed by the dideoxy termination method (Sanger et al., 1977), using a Sequenase kit (US Biochemical), and $\left[{ }^{35}\right.$ S]dATP $\mathrm{S}$ (New England Nuclear). Nested deletions were constructed using the Double Stranded Nested Deletion Kit (Pharmacia) to determine the first strand sequence. The second strand was sequenced using custom oligonucleotide primers. Double-stranded template DNA was prepared according to Kraft et al. (1988). Acrylamide and urea gels of $8 \%(w / v)$ were run and dried on a Bio-Rad model 583 gel dryer. Dried gels were exposed to Kodak X-OMat AR film at room temperature and developed. DNA and protein sequences were analysed using GCG software (Devereux et al., 1984). The PROSITE database was accessed using the MOTIFs program of GCG software (Devereux et al., 1984).

Expression of C. albicans PDE1 in S. cerevisiae. C. albicans $P D E 1$ was subcloned into the $S$. cerevisiae expression vector p138NB (McHale et al., 1991), which is a derivative of p138 (Livi et al., 1990). This expression vector contains the TRP1 selectable marker and partial $2 \mu$ sequences for maintenance at high copy number. Expression is driven by the copper-inducible CUP1 gene promoter. An AvaII-SfcI (filled in) fragment of pLH42 containing $C$. albicans PDE1 (Fig. 1b) was inserted into the NcoI-Sall (filled in) sites of the multiple cloning site downstream of the CUP1 promoter and upstream of the $S$. cerevisiae CYC1 transcription terminator. Since AvaII cuts within the PDE1 coding region, the $5^{\prime}$ end of the gene was repaired with annealed synthetic oligonucleotides which formed an NcoI site at the $5^{\prime}$ end and AvaII site at the $3^{\prime}$ end. The resulting plasmid, $\mathrm{pLH} 44$, was introduced into $S$. cerevisiae PDEase-deficient strain GL62 ( $p$ de 1::LEU2 pde2::URA3) (Table 1).

Cyclic nucleotide hydrolysis assays. Cells were grown in $\mathrm{SC}-$ Leu liquid medium to $\mathrm{OD}_{540} 1.0$ and induced with $150 \mu \mathrm{M}$ $\mathrm{CuSO}_{4}$ for $4 \mathrm{~h}$. Cells expressing recombinant PDE1 were lysed and extracts prepared as previously described (McHale et al., 1991). The resulting $100000 \mathrm{~g}$ supernatant was utilized in cyclic nucleotide hydrolysis assays.

PDEase activity was assayed using a modification of the method of Davis \& Daly (1979), as described previously (Torphy \& Cieslinski, 1990). The reaction was initiated with either enzyme or substrate and incubated at $30^{\circ} \mathrm{C}$. Incubation time was varied depending on the amount of enzyme activity. All assays were conducted in the linear range of the reaction, where less than $20 \%$ of the initial substrate is hydrolysed. Kinetic assays were controlled so as to limit substrate hydrolysis to no greater than $10 \%$. Kinetics were analysed with a KINPAC computer program (Cleland, 1979) using a non-linear least-squares regression analysis. $K_{\mathrm{m}}$ and $V_{\max }$ values reported are the mean of duplicate measurements on lysates of two individual clones of GL62 cells containing pLH44.

When screening compounds for PDEase inhibition, the enzyme was preincubated with the compounds for approximately $10 \mathrm{~min}$ at room temperature. Reactions were initiated with the substrate and the samples incubated for $30 \mathrm{~min}$ at $30^{\circ} \mathrm{C}$. Values reported are the mean of duplicate measurements with variations of less than $5 \%$. Dilution curves indicated linear hydrolysis within the range of dilution, eliminating the possible effect on enzymic activity of contaminants in cell lysates (such as residual $\left(\mathrm{Cu}^{2+}\right)$. As a control for the possible effect of cations in the cell lysis buffer, enzymic activity was measured in the presence and absence of EDTA; full enzymic activity was observed in the presence of up to $15 \mathrm{mM}$ EDTA.

Southern blotting. Chromosomal DNA $(5 \mu \mathrm{g})$ was digested to completion with restriction enzymes and separated on $1 \%$ (w/v) agarose gels. Standard methods (Sambrook et al., 1989) were used for agarose gel electrophoresis and DNA transfer to nitrocellulose membranes (Schleicher and Schuell).

Probes were prepared by random priming using the Pharmacia OligoLabelling $\mathrm{Kit}$ and $\left[{ }^{32} \mathrm{P}\right] \mathrm{dCTP} \quad\left(3000 \mathrm{Ci} \mathrm{mmol}{ }^{-1}\right.$, $\left.111 \mathrm{TBq} \mathrm{mmol}{ }^{-1} ; \mathrm{ICN}\right)$. Unincorporated nucleotides were separated from labelled fragments using NICK columns (Pharmacia). Hybridizations were carried out at $42{ }^{\circ} \mathrm{C}$ in $50 \%$ (v/v) formamide (Sambrook et al., 1989). Wash conditions were $2 \times$ SSC, $0.5 \%(\mathrm{w} / \mathrm{v}) \mathrm{SDS}$ at $42{ }^{\circ} \mathrm{C}$ for low stringency and $0.5 \times$ SSC, $0 \cdot 1 \%(\mathrm{w} / \mathrm{v})$ SDS at $68^{\circ} \mathrm{C}$ for high stringency (Sambrook et al., 1989).

Fragments of the S. cerevisiae PDE1 and PDE2 genes which were used as probes in genomic Southern blots were obtained by PCR amplification of genomic S. cerevisiae DNA. Synthetic oligonucleotide primers were prepared to amplify sequences corresponding to nucleotides $213-1005$ of the 1107 bp PDE1 coding region (Nikawa et al., 1987) and nucleotides 439-1578 of the $1581 \mathrm{bp}$ coding region of PDE2 (Sass et al., 1986). Restriction sites were incorporated into the PCR primers for cloning of fragments into pUC vectors. An $A v a I I-S c a I$ fragment of pLH42 was used as a C. albicans PDE1 probe (Fig. $1 \mathrm{~b}$ ).

\section{RESULTS}

\section{Isolation of a C. albicans cyclic nucleotide PDEase- encoding gene via complementation in S. cerevisiae}

S. cerevisiae contains two genes encoding cAMP PDEases: PDE1, which encodes a low-affinity enzyme of $42 \mathrm{kDa}$ (Londesborough \& Suoranta, 1983; Sass et al., 1986) and PDE2, encoding a high-affinity $61 \mathrm{kDa}$ protein (Nikawa et al., 1987; Suoranta \& Londesborough, 1984; Wilson \& Tatchell, 1988). Our initial attempt at isolating PDEaseencoding genes from $C$. albicans involved crosshybridization with $S$. cerevisiae genes. ${ }^{32}$ P-labelled fragments corresponding to the coding regions of the $S$. cerevisiae $P D E 1$ and $P D E 2$ genes failed to detect any cross-hybridizing restriction fragments in $C$. albicans genomic DNA even at low stringency (data not shown).

Our next approach involved complementation in a $S$. cerevisiae mutant strain. Cells containing null mutations in both PDE1 and PDE2, or in PDE2 alone, are viable, but exhibit specific growth-arrest phenotypes such as heatshock sensitivity, the inability to grow under starvation conditions, or the inability to survive prolonged nitrogen starvation (Colicelli et al., 1989; Nikawa et al., 1987; Sass et al., 1986; Wilson \& Tatchell, 1988). These phenotypes are a consequence of increased intracellular cAMP levels. We utilized the heat-shock sensitivity of a PDE2-deficient S. cerevisiae mutant strain, RW134-2C (Wilson \& Tatchell, 1988), to screen a YEp13-based $C$. albicans genomic library for a complementing clone. A single clone was isolated (after $7 \mathrm{~d}$ growth) capable of reversing the heat- 
(a)

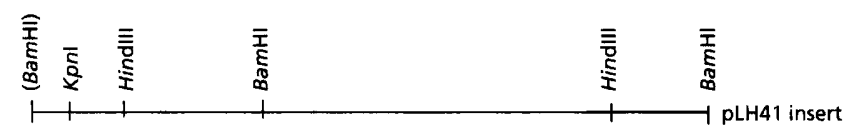

(b)
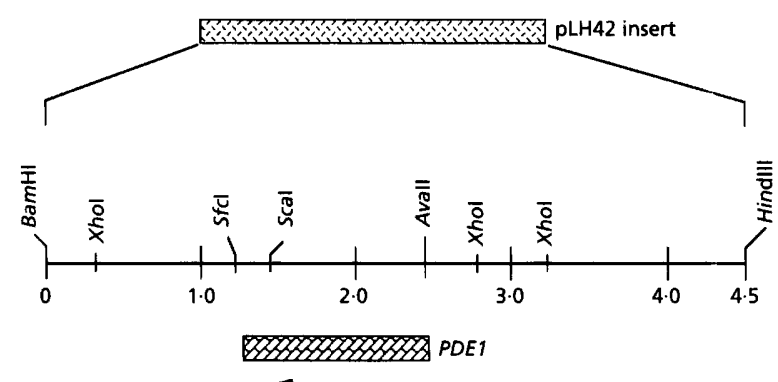

Fig. 1. (a) Diagram of $9 \mathrm{~kb}$ insert fragment from plasmid pLH41. All BamHI and HindIII sites are included; additional Kpnl sites not shown in the map are present. Sites in parentheses indicate those destroyed by ligation into YEp13. The $4.5 \mathrm{~kb}$ BamHI-HindIII insert, the smallest fragment tested capable of complementing the heat-shock phenotype of RW134-2C, is indicated by the lower, shaded bar. This fragment was subcloned from its original YEp351 construct, pLH42, into pUC19 to create pLH43 for DNA sequencing. (b) The $4.5 \mathrm{~kb}$ BamHI-HindIII insert with restriction sites predicted from DNA sequencing. The bar below the map represents the ORF encoding PDE 1, with the arrow indicating the direction of transcription. Locations of the Avall and Sfd sites used in subcloning PDE1 for expression, the Avall and Scal sites used to create the $C$. albicans PDE1 probe for genomic Southern analysis, and Xhol sites necessary for interpretation of Southern analyses are included.

shock-sensitive phenotype in RW134-2C. The activity of the transforming plasmid (designated pLH41) was confirmed by demonstrating co-segregation of heat-shock resistance and the $\mathrm{Leu}^{+}$phenotype in cells grown in nonselective media. pLH41 also was found to confer heatshock resistance when reintroduced into RW134-2C.

Partial restriction mapping of pLH41 indicated it contained a $9 \mathrm{~kb}$ insert (Fig. 1a). Fragments of the pLH41 insert digested with BamHI and/or HindIII were subcloned into YEp351 (Hill et al., 1986) to define a smaller active sub-fragment. YEp351 $(5.6 \mathrm{~kb})$, like YEp13 $(10.7 \mathrm{~kb})$, contains the LEU2 gene as a selectable marker and $2 \mu$ sequences for maintenance at high copy number. One plasmid, pLH42, which contains the central $4.5 \mathrm{~kb}$ Bam HI-HindIII fragment of the pLH41 insert (Fig. 1a) was found to be active. RW134-2C cells harbouring pLH42 grew in only $2 \mathrm{~d}$ following heat shock as compared to the $7 \mathrm{~d}$ required for growth of RW134-2C(pLH41). It is not clear why pLH42 complemented the pde 2: :UR A3 mutation more efficiently than pLH41. The weak complementation observed with pLH41 may be due to a lower copy number, which may be a function of its larger size (approx. $20 \mathrm{~kb}$ ) compared to pLH42 (approx. $10 \mathrm{~kb}$ ) (see Broach, 1983). Alternatively, the $9 \mathrm{~kb}$ pLH41 insert may contain sequences (absent in pLH42) that have a negative influence on copy number or plasmid maintenance. Since the PDE1 open reading frame (ORF) is located in the centre of the $4.5 \mathrm{~kb}$ insert in pLH42 (see below), it is unlikely that any specific cis-acting sequences required for transcriptional repression were eliminated during subcloning.

\section{DNA sequence of the complementing clone}

The entire complementing $4.5 \mathrm{~kb}$ Bam HI-HindIII fragment was sequenced and found to contain a long ORF (Fig. 1b) predicting a 426-amino-acid protein (Fig. 2) with identity to known PDEases (Fig. 2), especially with the low-affinity cAMP PDEase of S. cerevisiae (Nikawa et al., 1987) and the cyclic nucleotide PDEase, PD, of the slime mould Dictyostelium discoideum (Lacombe et al., 1986). A multiple alignment of these three sequences is shown in Fig. 3. Based on the extensive similarities between the $C$. albicans and $S$. cerevisiae proteins, we designated the gene that we have cloned PDE1. Since, in theory, expression of any enzyme capable of hydrolysing cAMP would have been detected in our complementation assay, it is not surprising that the low-affinity cAMP PDEase from $C$. albicans was found to complement the phenotype associated with elevated cAMP content caused by a lack of the high-affinity enzyme. In fact, cDNAs encoding several different types of mammalian cAMP PDEases have been cloned via complementation in yeast (Colicelli et al., 1989; Michaeli et al., 1993).

Although the three sequences shown in Fig. 3 display several regions with a high degree of conservation, the overall percent identity at both the nucleotide and amino acid level was rather low (Table in Fig. 3). Values of $44 \%$ identity at the nucleotide level between the $S$. cerevisiae and C. albicans $P D E 1$ sequences may account for the failure to isolate the gene by cross-hybridization.

The $5^{\prime}$ untranslated region (UTR) of PDE1 contains some elements frequently observed in eukaryotic promoters (Fig. 2), including two putative TATA elements at -34 and - 66 and CCAATCT (with one mismatch) at -72 (Nussinov, 1990). The sequences adjacent to the putative AUG codon compare favourably with a consensus sequence (AAAAAAAUGUCU) derived from the analysis of many S. cerevisiae genes (Hamilton et al., 1987). Several putative polyadenylation signals, all with a single mismatch from the consensus AATAAA (Proudfoot \& Brownlee, 1976), are present within the $3^{\prime}$ UTR.

\section{Structural features of the deduced PDE1 protein}

Analysis of the PROSITE database for consensus sequences in C. albicans PDE1 associated with a biological function revealed a sequence with similarity to a motif called a cAMP PDEase class-II signature which is present in both $S$. cerevisiae PDE1 and D. discoideum PD, but not in any of the other PDEases sequenced to date including several mammalian enzymes, the Drosophila dnc gene product, and S. cerevisiae PDE2 (Fig. 4a) (Beavo \& Reifsnyder, 1990; Charbonneau et al., 1986). This signature sequence was not derived from any residues shown to be of importance for catalysis but was chosen due to the fact that three conserved histidine residues are found in this region. Differences between the consensus sequence and $C$. albicans PDE1 amino acid sequence are indicated in Fig. 


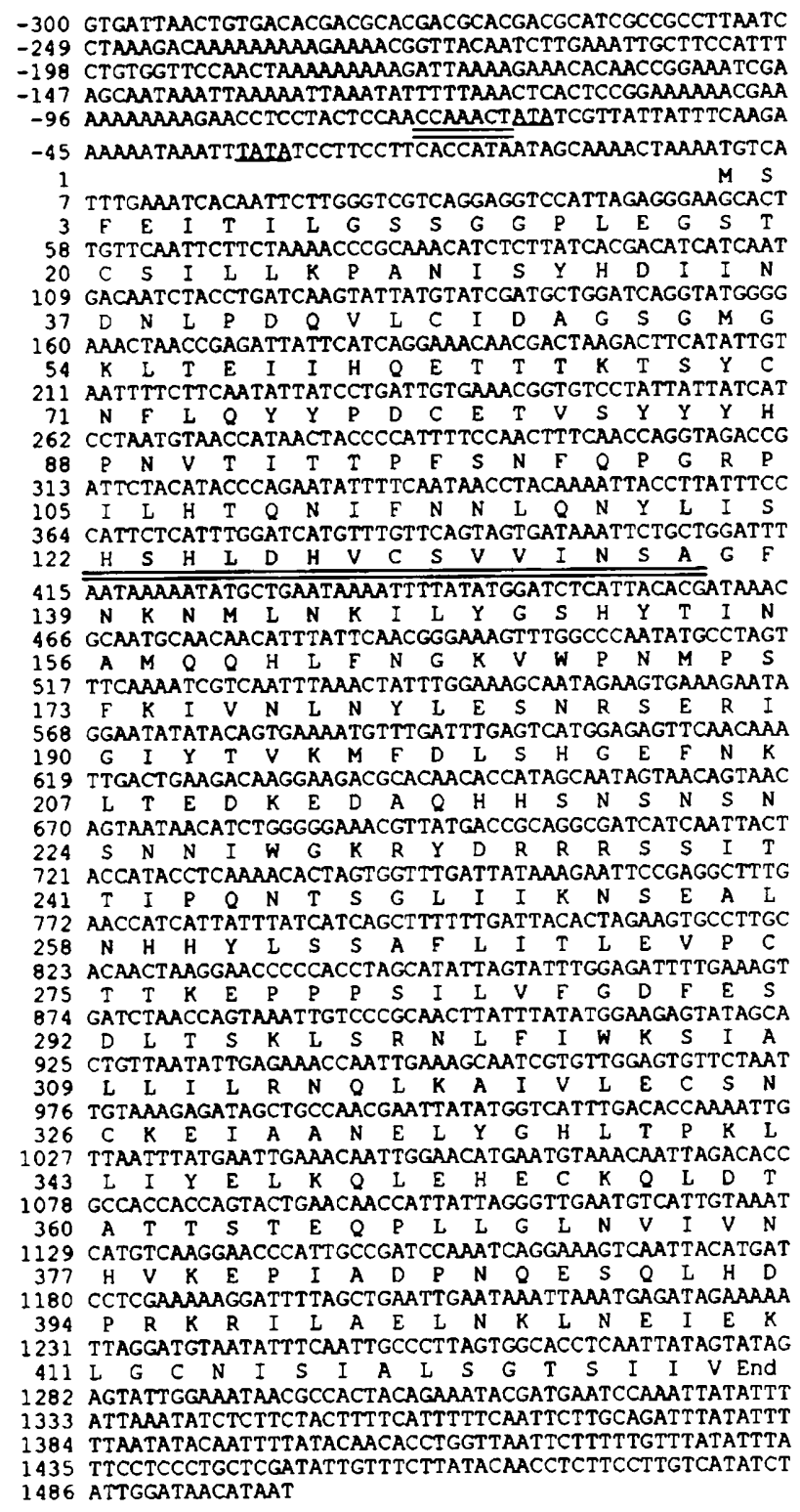

Fig. 2. Nucleotide sequence of $C$. albicans PDE1, with predicted amino acid translation. Putative regulatory elements frequently found in eukaryotic promoters are noted, including TATA underlined at positions -34 and -66 and CCAATCT underlined twice (with one mismatch) at -72 . The CAMP PDEase class-II signature motif is underlined twice in the amino acid sequence.

4(a) by arrows. Based on these data, we propose that the class-II signature sequence be modified to accommodate the amino acid sequence predicted by $C$. albicans PDE1.

The database also indicated the presence of a leucine zipper motif in $S$. cerevisiae PDE1, a less well-matched leucine zipper in C. albicans PDE1 and no evidence of this motif in the $D$. discoideum sequence (Fig. 4b) (Landschulz et al., 1989). S. cerevisiae PDE1 has been demonstrated to exist as a dimer (Londesborough \& Suoranta, 1983), but the leucine zipper was not determined to be the means by which dimerization occurs. Although this conserved motif was detected in $S$. cerevisiae PDE1, the region

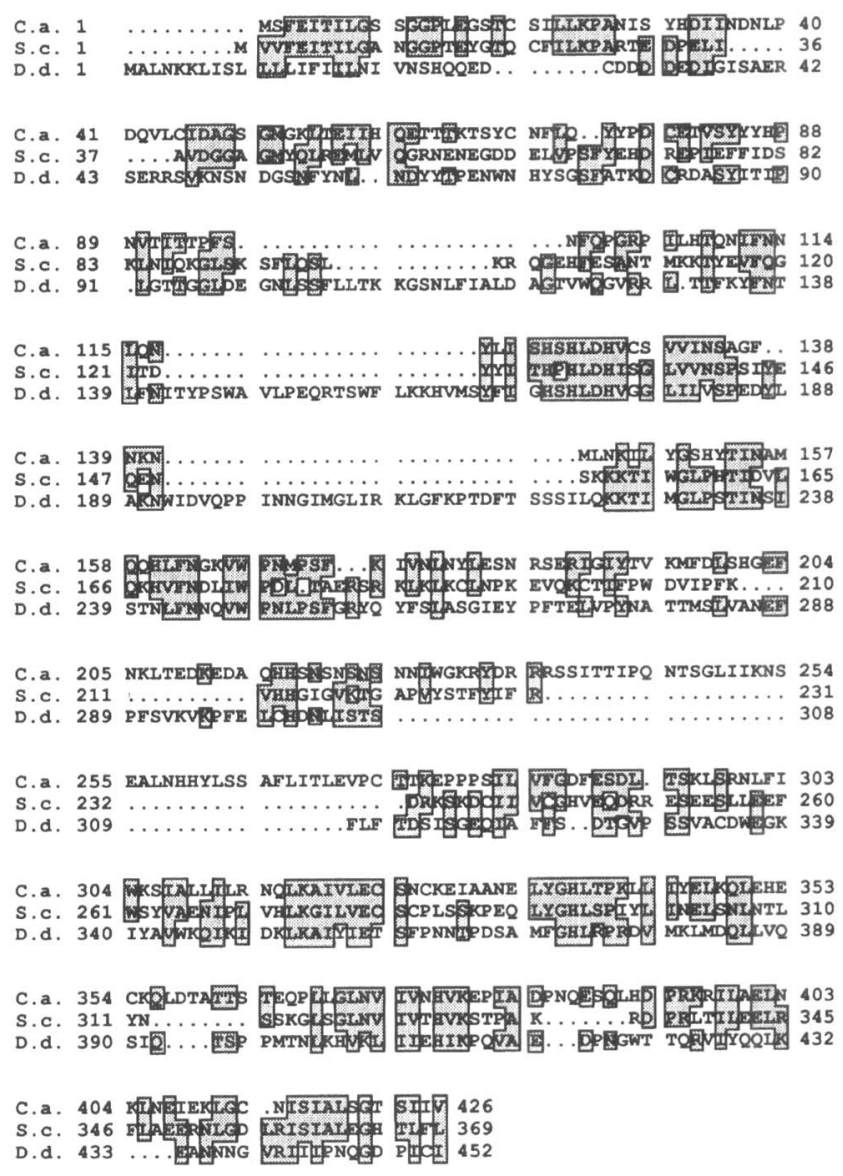

C.a.

S.C.

D.d.

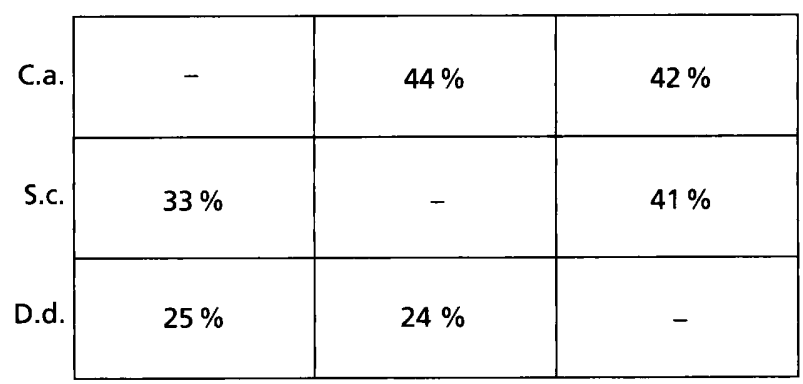

Fig. 3. Multiple alignment of the amino acid sequences of $C$. albicans PDE1 (C.a.), S. cerevisiae PDE1 (S.C.), and D. discoideum PD (D.d.) as generated by the PILEUP program of GCG software (Devereux et al., 1984). Identical and conservatively replaced amino acids are boxed and shaded. Conservative replacements were judged using the following rules: $A=G ; D=E ; Q=N$; $\mathrm{S}=\mathrm{T} ; \mathrm{K}=\mathrm{R} ; \mathrm{I}=\mathrm{L}=\mathrm{V}$. The table shows percentage nucleotide and amino acid identities between C. albicans PDE1 (C.a.), $S$. cerevisiae PDE1 (S.C.), and D. discoideum PD (D.d.). Values on the upper diagonal represent nucleotide identities from optimal alignments generated using the GAP program of GCG software (Devereux et al., 1984). Values on the lower diagonal are amino acid identities tabulated by hand using the optimal alignment generated by the GAP program (Devereux et al., 1984).

containing the putative leucine zipper was not predicted to assume $\alpha$-helical conformation by predictive algorithms (Devereux et al., 1984). The $\alpha$-helical conformation was 
(a)

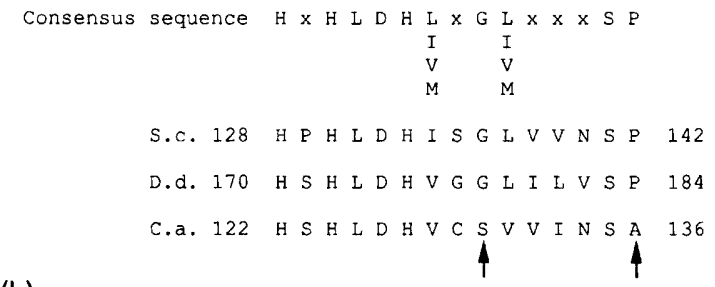

(b)

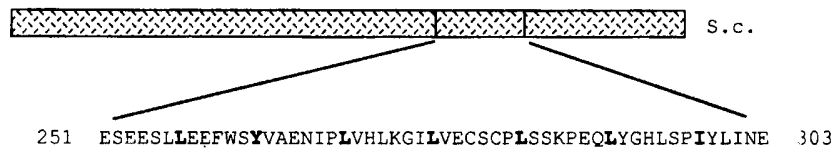

EIIIIIIIIIIIIIIIIIIIIIIIIIIIIIXIIIXIIII- с.а.

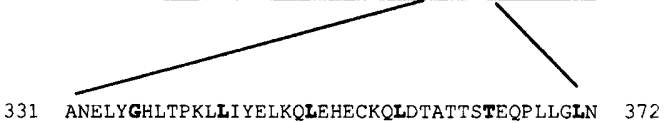

Fig. 4. (a) Consensus sequence for the PDEase class-II signature sequence from the PROSITE database and corresponding occurrences of this motif in $S$. cerevisiae PDE1 (S.C.), $D$. discoideum PD (D.d.), and C. albicans PDE1 (C.a.). Positions where any amino acid is acceptable are indicated by ' $x$ ' and positions where conservative replacements are allowed are noted by a list of alternatives. Arrows indicate the positions where the $C$. albicans sequence fails to conform to the consensus sequence. (b) Schematic diagram of predicted $S$. cerevisiae PDE1 (S.C.) and C. albicans PDE1 (C.a.) sequences. Regions corresponding to putative leucine zipper motifs are boxed and sequences from these regions expanded below. Residues required for leucine zipper formation are highlighted in boldface type.

Table 2. CAMP and CGMP hydrolysis

\begin{tabular}{|llll|}
\hline Strain & Plasmid & PDEase activity (units)* \\
\cline { 3 - 4 } & & $\begin{array}{c}\text { cAMP } \\
\text { hydrolysis }\end{array}$ & $\begin{array}{c}\text { cGMP } \\
\text { hydrolysis }\end{array}$ \\
\hline GL62 & p138NB & 0 & 0 \\
DC17 & None & 0.078 & 0.015 \\
GL62 & pLH44 & $2 \cdot 1$ & 2.5 \\
RW134-2C & YEp13 & 0.023 & 0.013 \\
RW134-2C & pLH41 & 0.024 & 0.014 \\
RW134-2C & pLH42 & 1.8 & 1.7 \\
\hline
\end{tabular}

$* 1$ unit $=1 \mathrm{nmol} \mathrm{cNMP}$ hydrolysed $\min ^{-1}(\mathrm{mg} \text { protein })^{-1}$ at $30^{\circ} \mathrm{C}$. Assays were done in duplicate with differences of less than $5 \%$ between replicates.

predicted for the region containing the less well-matched leucine zipper pattern in C. albicans PDE1, but the heptad leucine repeat may not be well enough conserved to be functional (Fig. 4b).

$D$. discoideum $\mathrm{PD}$ is an extracellular enzyme secreted by means of a classical signal peptide (Lacombe $e t$ al., 1986). There is no evidence for an $\mathrm{N}$-terminal signal peptide in
Table 3. Effect of divalent cations on recombinant PDEase activity

\begin{tabular}{|lrrr|}
\hline Cation & $\begin{array}{c}\text { Concn } \\
(\mathrm{mM})\end{array}$ & $\begin{array}{l}\text { Specific } \\
\text { activity } \\
\text { (units) }\end{array}$ & $\begin{array}{c}\text { \% of } \\
\text { control }\end{array}$ \\
\hline Control & - & 374 & 100 \\
$\mathrm{Ca}^{2+}$ & 1 & 358 & 96 \\
& 10 & 366 & 98 \\
$\mathrm{Cu}^{2+}$ & 1 & 45 & 12 \\
& 10 & 10 & 3 \\
$\mathrm{Mg}^{2+}$ & 1 & 378 & 101 \\
& 10 & 384 & 103 \\
$\mathrm{Mn}^{2+}$ & 1 & 364 & 97 \\
& 10 & 368 & 98 \\
$\mathrm{Zn}^{2+}$ & 1 & 94 & 25 \\
& 10 & 23 & 6 \\
\hline
\end{tabular}

$* 1$ unit $=1 \mathrm{nmol}$ cAMP hydrolysed $\min ^{-1}(\mathrm{mg} \text { protein })^{-1}$ at $30^{\circ} \mathrm{C}$. Reactions contained $0.5 \mathrm{mM}$ cAMP as substrate. Assays were done in duplicate with differences of less than $5 \%$ between replicates.

either $C$. albicans PDE1 or S. cerevisiae PDE1, consistent with their intracellular localization (Fujimoto et al., 1974; Gunasekaran et al., 1976).

\section{Expression of C. albicans PDE1 in S. cerevisiae}

Demonstration that the $C$. albicans PDE1 gene product hydrolyses cAMP was achieved following expression in $S$. cerevisiae. The gene was subcloned into the $S$. cerevisiae expression vector $\mathrm{p} 138 \mathrm{NB}$ which contains the copperinducible CUP1 promoter. The resulting plasmid (pLH44) was introduced into PDEase-deficient $S$. cerevisiae strain GL62 (Table 1) and expression was induced by growing cells in the presence of $\mathrm{CuSO}_{4}$. Cell lysates were assayed for cyclic nucleotide hydrolysis (Table 2). Whereas cells of GL62 harbouring p138NB alone showed no detectable cAMP or cGMP hydrolysis activity, cells with pLH44 showed a 27 -fold increase in cAMP hydrolysis activity compared to the untransformed wildtype strain DC17. Furthermore, p138NB, unlike pLH44, was incapable of complementing the heat-shock-sensitive phenotype of GL62 (data not shown).

Lysates of RW134-2C cells carrying the original pLH41 complementing plasmid contained nearly background (i.e. endogenous PDE1) enzymic activity, whereas pLH42, which contains the smallest active subclone, conferred expression levels comparable to pLH44. This may account for the observed delay in growth following the heat shock assay with pLH41 (7 d) versus pLH42 $(2 \mathrm{~d})$. These data suggest that only a slight reduction in intracellular cAMP levels is required to reverse the heatshock phenotype in strain RW134-2C. Thus, there is a significant difference between the amount of enzyme required in vivo to break down enough cAMP to allow cells to survive heat shock, and the amount of enzyme required to detect cAMP hydrolysis in our in vitro assay. 
Table 4. Effect of different compounds on recombinant PDEase activity

\begin{tabular}{|lrrr|}
\hline Compound & $\begin{array}{c}\text { Concn } \\
\text { (mM) }\end{array}$ & $\begin{array}{c}\text { Specific } \\
\text { activity } \\
\text { (units) }\end{array}$ & $\begin{array}{c}\text { \% of } \\
\text { control }\end{array}$ \\
\hline Control & - & 414 & 100 \\
EDTA & 1 & 404 & 98 \\
& 10 & 476 & 115 \\
& 15 & 426 & 103 \\
EGTA & 1 & 403 & 97 \\
& 10 & 383 & 93 \\
2-ME & 1 & 325 & 79 \\
& 10 & 130 & 31 \\
DTT & 1 & 67 & 16 \\
& 10 & 29 & 7 \\
Aminophylline & 1 & 473 & 114 \\
& 10 & 141 & 34 \\
IBMX & 1 & 352 & 85 \\
& 10 & 273 & 66 \\
Imidazole & 1 & 417 & 101 \\
& 10 & 345 & 86 \\
Caffeine & 1 & 517 & 125 \\
& 10 & 211 & 51 \\
\hline
\end{tabular}

$* 1$ unit $=1 \mathrm{nmol} \mathrm{cAMP}$ hydrolysed $\mathrm{min}^{-1}(\mathrm{mg} \text { protein })^{-1}$ at $30^{\circ} \mathrm{C}$. Reactions contained $0.5 \mathrm{mM}$ cAMP as substrate. Assays were done in duplicate with differences of less than $5 \%$ between replicates.

\section{Biochemical characterization of recombinant C. albicans PDE1 expressed in S. cerevisiae}

$K_{\mathrm{m}}$ and $V_{\max }$ values were determined by assay of lysates of $S$. cerevisiae PDEase-negative cells in which $C$. albicans PDE1 was expressed. Using cAMP as substrate, $K_{\mathrm{m}}$ and $V_{\max }$ for the recombinant enzyme were (mean $\pm \mathrm{SE}$ ) 0.49 $( \pm 0 \cdot 048) \mathrm{mM}$ and $1172( \pm 118) \mathrm{nmol} \mathrm{\textrm {min } ^ { - 1 }}$ (mg protein $)^{-1}$, respectively. A lower $K_{\mathrm{m}}$ of $0.25( \pm 0.022) \mathrm{mM}$ was calculated for cGMP as substrate with a $V_{\max }$ of 44 $( \pm 2.7) \mathrm{nmol} \mathrm{min}^{-1}$ (mg protein) ${ }^{-1}$. The double reciprocal plots for all studies were linear with $r^{2}=0.99$. Within a single experiment, the standard errors were always $\leqslant 10 \%$ of the calculated kinetic constants.

Divalent cation requirements of this enzyme were also investigated (Table 3). Addition of cations at 1 and $10 \mathrm{mM}$ concentrations indicated that $\mathrm{Ca}^{2+}, \mathrm{Mg}^{2+}$ and $\mathrm{Mn}^{2+}$ had essentially no effect on C. albicans PDE1 activity, while $\mathrm{Cu}^{2+}$ and $\mathrm{Zn}^{2+}$ were strongly inhibitory. Addition of EDTA and EGTA (Table 4) also did not significantly alter C. albicans PDE1 activity. Moderate and strong inhibition were noted in the presence of 2-mercaptoethanol (2-ME) and dithiothreitol (DTT), respectively.

The PDEase inhibitors aminophylline and 3-isobutyl-1methylxanthine (IBMX) had moderate inhibitory effects on the activity of $C$. albicans PDE1 (Table 4). Imidazole and caffeine were also moderate inhibitors of enzyme activity. C. albicans PDE1 activity was not stimulated by addition of $\mathrm{Ca}^{2+} /$ calmodulin (data not shown). Heating of the cell lysate at $100^{\circ} \mathrm{C}$ for $1 \mathrm{~min}$ completely inactivated C. albicans PDE1 activity.

\section{Occurrence of PDE1 in related species}

The occurrence of $C$. albicans and S. cerevisiae PDE1 homologues in known pathogenic Candida species and organisms demonstrated by rRNA sequencing to be most closely related to C. albicans (Barns et al., 1991) was investigated using Southern blots of genomic DNA. $S$. cerevisiae PDE1 hybridized to its corresponding genomic $X b_{o} \mathrm{I}$ fragment, but failed to detect genomic sequences from C. albicans and C. stellatoidea (Fig. 5a). An identical blot probed with an internal $A v a I I-S c a$ I fragment of $C$. albicans PDE1 showed a lack of hybridization with $S$. cerevisiae DNA, but detected a single fragment in DNA from $C$. albicans and C. stellatoidea (Fig. 5b). All other Candida species tested (C. glabrata, C. guilliermondii, $C$. keyfr, C. krusei, C. lusitaniae, C. parapsilosis, C. tropicalis and $C$. viswanathii) showed no cross-hybridization using either gene as a probe. These data suggest that either these organisms do not have PDE1-like genes, or, as is the case for the PDE1 genes of $C$. albicans and $S$. cerevisiae, nucleotide conservation between the genes of the various species is below the point at which it can be detected by low-stringency hybridization.

\section{DISCUSSION}

We have isolated a $C$. albicans gene (PDE1), encoding a cyclic nucleotide PDEase, by complementation in a $S$. cerevisiae PDEase-deficient mutant. Sequence comparisons indicated that $C$. albicans PDE1 is a homologue of $S$. cerevisiae PDE1 and shares identity with the extracellular cAMP PDEase of $D$. discoideum. The conclusion that the PDE1 proteins from $C$. albicans and $S$. cerevisiae are homologues is further substantiated by the close similarity of their biochemical characteristics. $K_{\mathrm{m}}$ values calculated for the $C$. albicans enzyme compare favourably with the $K_{\mathrm{m}}$ of $0.25 \mathrm{mM}$ for cAMP and $0.16 \mathrm{mM}$ for cGMP measured for $S$. cerevisiae PDE1 (Fujimoto et al., 1974); Londesborough (1982) calculated a slightly lower $K_{\mathrm{m}}$ of $0.13 \mathrm{mM}$ for the $S$. cerevisiae enzyme in the presence of cAMP. The effects of divalent cations on $C$. albicans and $S$. cerevisiae PDE1 activity are essentially identical, with $\mathrm{Ca}^{2+}$, $\mathrm{Mg}^{2+}$ and $\mathrm{Mn}^{2+}$ being neither required nor inhibitory, strong inhibition observed in the presence of $\mathrm{Cu}^{2+}$ and $\mathrm{Zn}^{2+}$, and no effect in the presence of $10 \mathrm{mM}$ EDTA (Fujimoto et al., 1974; Londesborough, 1982). Londesborough \& Suoranta (1983) concluded that a tightly bound $\mathrm{Zn}^{2+}$ ion accounted for the insensitivity of S. cerevisiae PDE1 to EDTA; this has yet to be investigated for the $C$. albicans enzyme. Similar to results for $C$. albicans PDE1, inhibition of the $S$. cerevisiae enzyme was observed in the presence of millimolar concentrations of 2-ME, with stronger inhibition at similar concentrations of DTT (Fujimoto et al., 1974) and moderate inhibition in the presence of $10 \mathrm{mM}$ theophylline $(45 \%)$ and $10 \mathrm{mM}$ caffeine $(20 \%)$. 


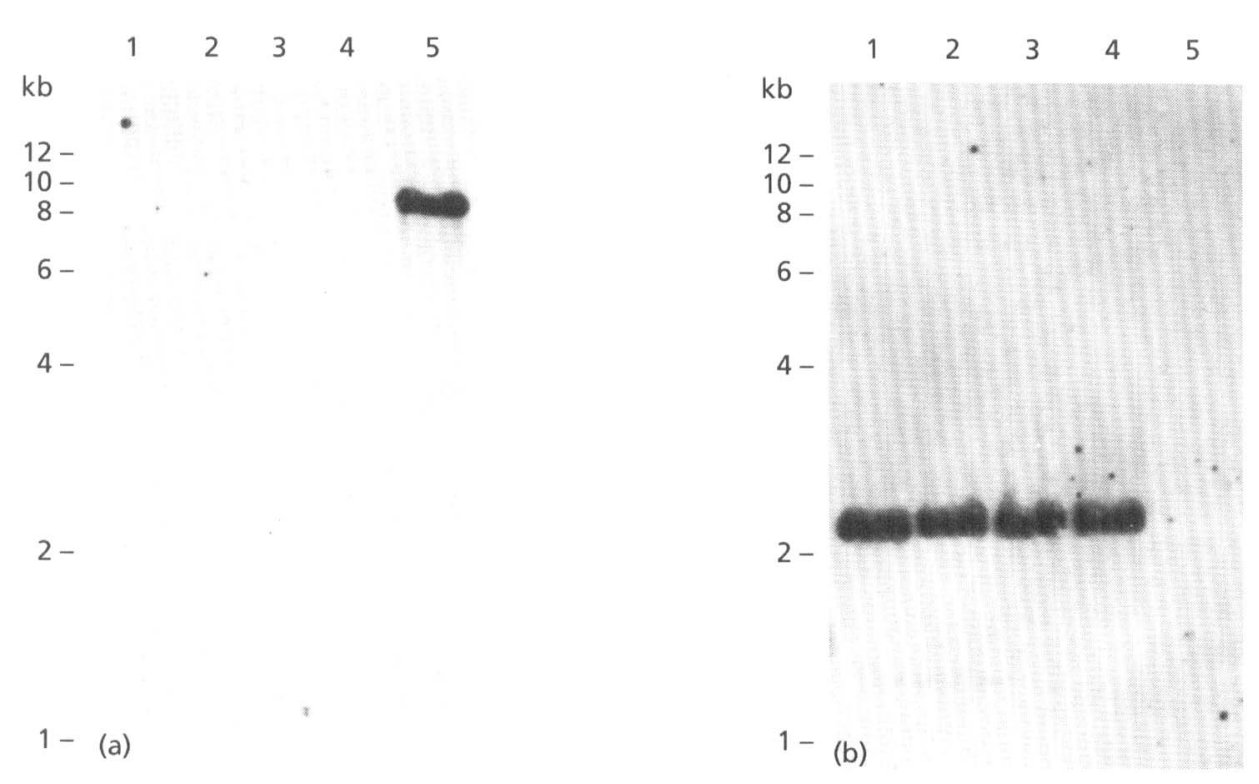

Fig. 5. Duplicate Southern blots of Xhol-digested genomic DNA from S. cerevisiae, C. albicans, and C. stellatoidea. (a) Probed with PCR-amplified fragment of S. cerevisiae PDE1. (b) Probed with Avall-Scal internal fragment from $C$. albicans PDE1. Lanes: 1, C. albicans B792; 2, C. albicans B311 (ATCC 32354); 3, C. stellatoidea ATCC 11006; 4, C. stellatoidea ATCC 36232; 5, S. cerevisiae F762.

Although the amino acid sequence of $D$. discoideum $P D$ is similar to that of the PDE1 genes, its $K_{\mathrm{m}}$ for cAMP is $5 \mu \mathrm{M}$, and when complexed with the phosphodiesterase inhibitor, PDI, the $K_{\mathrm{m}}$ increases to $2 \mathrm{mM}$ (Kessin et al., 1979). The regulation of $D$. discoideum $\mathrm{PD}$ expression has been the subject of intensive study due to its involvement in development of the organism (Podgorski et al., 1989); however, biochemical data for this enzyme are less abundant. In one study, $D$. discoideum $\mathrm{PD}$ was shown to have a higher affinity for cAMP than for cGMP (Van Ments-Cohen \& Haastert, 1989). Its extracellular localization and low $K_{\mathrm{m}}$ for cAMP suggest that although D. discoideum PD, C. albicans PDE1 and S. cerevisiae PDE1 share a high degree of amino acid sequence similarity, biochemically, the $S$. cerevisiae and $C$. albicans enzymes are much more similar to each other than to $D$. discoideum PD.

Comparison of our biochemical data with those previously determined for PDEases in $C$. albicans is complicated by the fact that previous measurements were obtained from whole-cell lysates containing more than one PDEase activity. The presence of more than one $C$. albicans PDEase activity was noted by Gunasekaran $e t$ al. (1976), who calculated $K_{\mathrm{m}}$ values for cAMP of 4.2 and $250 \mu \mathrm{M}$ by assaying ammonium sulfate fractions of cell lysates. Our $K_{\mathrm{m}}$ value of $490 \mu \mathrm{M}$ confirms our identification of the cloned gene as encoding the high- $K_{\mathrm{m}}$ C. albicans isozyme.

Egidy et al. (1990) reported partial purification and characterization of one C. albicans PDEase isozyme with a $K_{\mathrm{m}}$ for cAMP of between 0.5 and $0.8 \mu \mathrm{M}$ and a high specificity for cAMP. PDEase activity was enhanced by addition of $5 \mathrm{mM} \mathrm{Mg}{ }^{2+}$ or $\mathrm{Mn}^{2+}$ and inhibited $60 \%$ by $5 \mathrm{mM}$ theophylline or $4 \mathrm{mM}$ IBMX. The biochemical properties of this enzyme compare favourably with those obtained from whole-cell lysates (Gunasekaran et al., 1976) and are similar to those exhibited by the low $-K_{\mathrm{m}}$ PDEase of $S$. cerevisiae encoded by PDE2 (Londesborough, 1975, 1982; Sass et al., 1986; Suoranta \& Londesborough, 1984; Wilson \& Tatchell, 1988). Based on these observations and data presented in this communication, biochemical characteristics of PDEases in $C$. albicans appear to closely resemble those reported in S. cerevisiae, where PDE1 and PDE2 account for total cellular PDEase activity (Nikawa et al., 1987).

Since a minimum of two PDEase activities have been identified in C. albicans, our complementation assay, which screened several genome equivalents, should have revealed the gene encoding the high-affinity isozyme. In theory, all genes encoding enzymes which serve to decrease intracellular cAMP concentrations should have been detected. With its higher affinity for cAMP, the $C$. albicans homologue of $S$. cerevisiae PDE2 should have performed better in this capacity than $C$. albicans PDE1. It is possible that $C$. albicans PDE2 was not represented in the YEp13 genomic library utilized, that the promoter is nonfunctional in S. cerevisiae, or that when present on a high-copy-number vector, the high-affinity PDEase is lethal to $S$. cerevisiae cells. Attempts to isolate the second PDEase-encoding gene from $C$, albicans are in progress.

The relationship between intracellular cAMP levels and C. albicans morphogenesis is controversial (Chattaway et al., 1981; Egidy et al., 1990; Niimi et al., 1980; Sabie \& Gadd, 1992; Sullivan et al., 1983). The biochemical data presented herein, as well as those of Egidy et al. (1990), demonstrate that, minimally, millimolar concentrations of methylxanthines (theophylline, aminophylline and IBMX) and caffeine are required for moderate inhibition of both C. albicans PDEase isozymes. These data support 
the observations of a moderate rise in intracellular cAMP observed by Chattaway et al. (1981) in the presence of $5 \mathrm{mM}$ theophylline, but not the increased intracellular cAMP noted in the presence of micromolar theophylline and caffeine concentrations by Sabie \& Gadd (1992). Data derived from the use of millimolar concentrations of methylxanthines must also be interpreted cautiously since high concentrations of these compounds may affect enzymes other than PDEases (Pall, 1981).

While changes in intracellular cAMP content may occur concomitant with cellular differentiation, it remains unclear whether such changes represent a cause or effect of the process of development. Direct evidence to support or refute a cole for cAMP in C. albicans morphogenesis can be obtained by construction of a PDEase-deficient strain and evaluation of its ability to form hyphae. Further information could be gained by following expression of PDE1 during the yeast-to-hyphal transition. However, initial attempts to quantify expression on Northern blots have proven difficult due to low abundance of PDE1specific message in C. albicans cells (L. L. Hoyer, unpublished observation). Since reporter gene constructs are becoming available for C. albicans (Leuker et al., 1992), these could be utilized to study the activity of the PDE1 promoter throughout morphogenesis, and also the effect on expression of various media and inducers of the yeast-hyphal transition.

Finally, it is worth noting that, unlike the high-affinity PDEase isozyme which was described as highly specific for cAMP hydrolysis (Egidy et al., 1990), our enzyme hydrolyses cGMP with a higher affinity than for cAMP. This raises the possibility that PDE1 may play a larger role in regulation of intracellular cGMP levels than it does for cAMP. The isolation of $C$. albicans PDE1 is an important step toward gaining an understanding of the role of cyclic nucleotides in morphogenesis.

\section{ACKNOWLEDGEMENTS}

The authors would like to thank Carrie Frey and Kelly Tatchell for supplying strains, Jessica Gorman for providing the B792 genomic library, Carl Hoyer for his expertise in drawing figures, and Catherine Pachuk for ideas and lively discussions.

\section{REFERENCES}

Barns, S. M., Lane, D. J., Sogin, M. L., Bibeau, C. \& Weisburg, W. G. (1991). Evolutionary relationships among pathogenic Candida species and relatives. J Bacteriol 173, 2250-2255.

Beavo, J. A. \& Reifsnyder, D. H. (1990). Primary sequence of cyclic nucleotide phosphodiesterase isozymes and the design of selective inhibitors. Trends Pharmacol Sci 11, 150-155.

Birnboim, H. C. \& Doly, J. (1979). A rapid alkaline extraction procedure for screening recombinant plasmid DNA. Nucleic Acids Res 7, 1513-1523.

Broach, J. R. (1983). Construction of high copy yeast vectors using 2- $\mu \mathrm{m}$ circle sequences. Methods Envymol 101, 307-325.

Cantore, M. L., Galvagno, M. A. \& Passeron, S. (1980). Variations in the levels of cyclic adenosine $3^{\prime}-5^{\prime}$-monophosphate and in the activities of adenylate cyclase and cyclic adenosine $3^{\prime}-5^{\prime}$-mono- phosphate phosphodiesterase during aerobic morphogenesis of Mucor rouxii. Arch Biochem Biophys 199, 312-320.

Charbonneau, H., Beier, N., Walsh, K. A. \& Beavo, J. A. (1986). Identification of a conserved domain among cyclic nucleotide phosphodiesterases from diverse species. Proc Natl Acad Sci US A 83, 9308-9312.

Chattaway, F. W., Wheeler, P. R. \& O'Reilly, J. (1981). Involvement of adenosine $3^{\prime}: 5^{\prime}$-cyclic monophosphate in the germination of blastospores of Candida albicans. J Gen Microbiol 123, 233-240.

Cleland, W. W. (1979). Statistical analysis of enzyme kinetic data. Methods Enzymol 63, 103-138.

Colicelli, J., Birchmeier, C., Michaeli, T., O’Neill, K., Riggs, M. \& Wigler, M. (1989). Expression of three mammalian cDNAs that interfere with RAS function in Saccharomyces cerevisiae. Proc Natl Acad Sci US A 86, 3599-3603.

Davis, C. W. \& Daly, J. W. (1979). A simple direct assay of 3',5'cyclic nucleotide phosphodiesterase activity based on the use of polyacrylamide-boronate affinity gel chromatography. $J$ Cyclic Nucleotide Res 5, 65-74.

Devereux, J., Haeberli, P. \& Smithies, O. (1984). A comprehensive set of sequence analysis programs for the VAX. Nucleic Acids Res 12, 387-395.

Egidy, G. A., Paveto, M. C., Passeron, S. \& Galvagno, M. A. (1989). Relationship between cyclic adenosine $3^{\prime}: 5^{\prime}$-monophosphate and germination in Candida albicans. Exp Mycol 13, 428-432.

Egidy, G., Paveto, C., Passeron, S. \& Galvagno, M. A. (1990). cAMP levels and in situ measurement of cAMP related enzymes during yeast-to-hyphae transition in Candida albicans. Cell Biol Int Rep 14, 59-68.

Fujimoto, M., Ichikawa, A. \& Tomita, K. (1974). Purification and properties of adenosine $3^{\prime}, 5^{\prime}$-monophosphate phosphodiesterase from Baker's yeast. Arch Biochem Biophys 161, 54-63.

Gunasekaran, M., Hughes, W. T. \& Maguire, W. J. (1976). Cyclic 3',5'-nucleotide phosphodiesterase of Candida albicans. Microbios Lett 3, 47-53.

Hamilton, R., Watanabe, C. K. \& de Boer, H. A. (1987). Compilation and comparison of the sequence context around the AUG start codons in Saccharomyces cerevisiae mRNAs. Nucleic Acids Res 15, 3581-93.

Hicks, J. B. \& Herskowitz, I. (1976). Interconversion of yeast mating types. I. Direct observations of the action of the homothallism (HO) gene. Genetics 83, 245-258.

Hill, J. E., Myers, A. M., Koerner, T. J. \& Tzagoloff, A. (1986). Yeast/E. coli shuttle vectors with multiple unique restriction sites. Yeast 2, 163-167.

Hinnen, A., Hicks, J. B. \& Fink, G. R. (1978). Transformation of yeast. Proc Natl Acad Sci US A 75, 1929-1933.

Ito, H., Fukuda, Y., Murata, K. \& Kimura, A. (1983). Transformation of intact yeast cells treated with alkali cations. $J$ Bacteriol 153, 163-168.

Kessin, R. H., Orlow, S. J., Shapiro, R. I. \& Franke, J. (1979). Binding of inhibitor alters kinetic and physical properties of extracellular cAMP phosphodiesterase from Dictyostelium discoideum. Proc Natl Acad Sci US A 76, 5450-5454.

Kraft, R., Tardiff, J., Krauter, K. S. \& Leinwand, L. A. (1988). Using mini-prep plasmid DNA for sequencing double stranded templates with Sequenase $^{\mathrm{TM}}$. Bio Tecbniques 6, $544-547$.

Kwon-Chung, K. J., Hicks, J. B. \& Lipke, P. N. (1990). Evidence that Candida stellatoidea type II is a mutant of Candida albicans that does not express sucrose-inhibitable $\alpha$-glucosidase. Infect Immun 58, 2804-2808. 
Lacombe, M.-L., Podgorski, G. J., Franke, J. \& Kessin, R. H. (1986). Molecular cloning and developmental expression of the cyclic nucleotide phosphodiesterase gene of Dictyostelium discoideum.J Biol Chem 261, 16811-16817.

Landschulz, W. H., Johnson, P. F. \& McKnight, S. L. (1989). The DNA binding domain of the rat liver nuclear protein $C / E B P$ is bipartite. Science 243, 1681-1688.

Larsen, A. D. \& Sypherd, P. S. (1974). Cyclic adenosine $3^{\prime}-5^{\prime}-$ monophosphate and morphogenesis in Mucor racemosus. J Bacteriol $117,432-438$.

Leuker, C. E., Hahn, A.-M. \& Ernst, J. F. (1992). $\beta$-Galactosidase of Kluyveromyces lactis (Lac4p) as reporter of gene expression in Candida albicans and C. tropicalis. Mol \& Gen Genet 235, 235-241.

Livi, G. P., Ferrara, A., Roskin, R., Simon, P. L. \& Young, P. R. (1990). Secretion of $N$-glycosylated human recombinant interleukin- $1 \alpha$ in Saccharomyces cerevisiae. Gene 88, 297-301.

Londesborough, J. (1975). Soluble and membrane-bound cyclic AMP diesterase activity with a low Michaelis constant in Baker's yeast. FEBS Lett 50, 283-287.

Londesborough, J. (1982). Activity of cyclic-AMP phosphodiesterase in permeabilised cells of Baker's yeast. Eur J Biochem 126, 631-637.

Londesborough, J. \& Suoranta, K. (1983). The zinc-containing high- $K_{\mathrm{m}}$ cyclic nucleotide phosphodiesterase of Bakers' yeast. $J$ Biol Chem 258, 2966-2972.

Maresca, B., Medoff, G., Schlessinger, D., Kobayashi, G. S. \& Medoff, J. (1977). Regulation of dimorphism in the pathogenic fungus Histoplasma capsulatum. Nature 266, 447-448.

McHale, M. M., Cieslinski, L. B., Eng, W. K., Johnson, R. K., Torphy, T. J. \& Livi, G. P. (1991). Expression of human recombinant cAMP phosphodiesterase isozyme IV reverses growth arrest phenotypes in phosphodiesterase-deficient yeast. Mol Pbarmacol 39, 109-113.

McLaughlin, M. M., Cieslinski, L. B., Burman, M., Torphy, T. J. \& Livi, G. P. (1993). A low- $K_{\mathrm{m}}$, rolipram-sensitive, cAMP-specific phosphodiesterase from human brain. Cloning and expression of cDNA, biochemical characterization of recombinant protein, and tissue distribution of mRNA. J Biol Chem 268, 6470-6476.

Michaeli, T., Bloom, T. J., Martins, T., Loughney, K., Ferguson, K., Riggs, M., Rogers, L., Beavo, J. A. \& Wigler, M. (1993). Isolation and characterization of a previously undetected human cAMP phosphodiesterase by complementation of cAMP phosphodiesterase-deficient Saccharomyces cerevisiae. I Biol Chem 268, 12925-12932.

Niimi, M., Niimi, K., Tokunaga, J. \& Nakayama, H. (1980). Changes in cyclic nucleotide levels and dimorphic transition in Candida albicans. J Bacteriol 143, 1010-1014.

Nikawa, J.-l., Sass, P. \& Wigler, M. (1987). Cloning and characterization of the low-affinity cyclic AMP phosphodiesterase gene of Saccharomyces cerevisiae. Mol Cell Biol 7, 3629-3636.

Nussinov, R. (1990). Sequence signals in eukaryotic upstream regions. Critical Rev Biocbem Mol Biol 25, 185-224.

Odds, F. C. (1985). Morphogenesis in Candida albicans. CRC Crit Rev Microbiol 12, 45-93.

Pall, M. L. (1981). Adenosine $3^{\prime}, 5^{\prime}$-phosphate in fungi. Microbiol Rev 45, 462-480.

Paveto, C., Epstein, A. \& Passeron, S. (1975). Studies on cyclic adenosine $3^{\prime}, 5^{\prime}$-monophosphate levels, adenylate cyclase and phosphodiesterase activities in the dimorphic fungus Mucor rouxii. Arch Biochem Biopbys 169, 449-457.
Paznokas, J. L. \& Sypherd, P. S. (1975). Respiratory capacity, cyclic adenosine $3^{\prime}-5^{\prime}$-monophosphate, and morphogenesis of Mucor racemosus. J Bacteriol 124, 134-139.

Podgorski, G. J., Franke, J., Faure, M. \& Kessin, R. H. (1989). The cyclic nucleotide phosphodiesterase gene of Dictyostelium discoideum utilizes alternate promoters and splicing for the synthesis of multiple mRNAs. Mol Cell Biol 9, 3938-3950.

Proudfoot, N. J. \& Brownlee, G. G. (1976). 3' non-coding region sequences in eukaryotic messenger RNA. Nature 263, 211-214.

Rosenbluh, A., Mevarech, M., Koltin, Y. \& Gorman, J. A. (1985). Isolation of genes from Candida albicans by complementation in Saccharomyces cerevisiae. Mol \& Gen Genet 200, 500-502.

Sabie, F. T. \& Gadd, G. M. (1992). Effect of nucleosides and nucleotides and the relationship between cellular adenosine $3^{\prime}: 5^{\prime}$ cyclic monophosphate (cyclic AMP) and germ tube formation in Candida albicans. Mycopathologia 119, 147-156.

Sambrook, J., Fritsch, E. F. \& Maniatis, T. (1989). Molecular Cloning: a Laboratory Manual, 2nd edn. Cold Spring Harbor, NY: Cold Spring Harbor Laboratory.

Sanger, F., Nicklen, S. \& Coulson, A. R. (1977). DNA sequencing with chain-terminating inhibitors. Proc Natl Acad Sci USA 74, 5463-5467.

Sass, P., Field, J., Nikawa, J., Toda, T. \& Wigler, M. (1986). Cloning and characterization of the high-affinity cAMP phosphodiesterase of Saccharomyces cerevisiae. Proc Natl Acad Sci US A 83, 9303-9307.

Shepherd, M. G. (1991). Morphogenesis in Candida albicans. In Candida albicans Cellular and Molecular Biology, pp. 5-19. Edited by R. Prasad. Berlin: Springer-Verlag.

Sherman, F., Fink, G. R. \& Hicks, J. B. (1986). Laboratory Course Manual for Methods in Yeast Genetics. Cold Spring Harbor. Cold Spring Harbor Laboratory.

Sobel, J. D., Muller, G. \& Buckley, H. R. (1984). Critical role of germ tube formation in the pathogenesis of Candida vaginitis. Infect Immun 44, 576-580.

Stoker, N. G., Pratt, J. M. \& Holland, I. B. (1984). In vivo gene expression systems in prokaryotes. In Transcription and Translation. A Practical Approach, pp. 153-177. Edited by B. D. Hames \& S. J. Higgins. Oxford: IRL Press.

Sullivan, P. A., Chiew, Y. Y., Molloy, C., Templeton, M. D. \& Shepherd, M. G. (1983). An analysis of the metabolism and cell wall composition of Candida albicans during germ-tube formation. Can J Microbiol 29, 1514-1525.

Suoranta, K. \& Londesborough, J. (1984). Purification of intact and nicked forms of a zinc-containing, $\mathrm{Mg}^{++}$-dependent, low- $K_{\mathrm{m}}$ cyclic AMP phosphodiesterase from Bakers' yeast. J Biol Chem 259, 6964-6971.

Torphy, T. J. \& Cieslinski, L. B. (1990). Characterization and selective inhibition of cyclic nucleotide phosphodiesterase isozymes in canine tracheal smooth muscle. Mol Pharmacol 37, 206-214.

Van Ments-Cohen, M. \& Haastert, P. J. M. (1989). The cyclic nucleotide specificity of eight cAMP-binding proteins in Dictyostelium discoideum is correlated into three groups. $J$ Biol Chem 264, 8717-8722.

Wilson, R. B. \& Tatchell, K. (1988). $S R A 5$ encodes the low $-K_{\mathrm{m}}$ cyclic AMP phosphodiesterase of Saccbaromyces cerevisiae. Mol Cell Biol 8, 505-510.

Received 18 August 1993; revised 30 November 1993; accepted 13 January 1994. 